
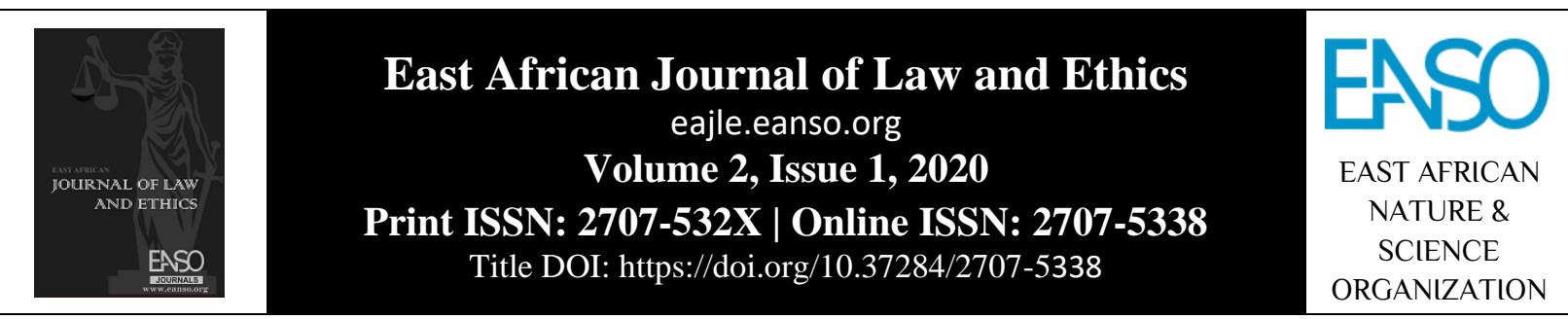

Original Article

\title{
Administration of Legal Issues in African Development for Global Sustainability
}

\author{
Dr. Edna Moi ${ }^{1 *}$, Prof. David Minja ${ }^{1} \&$ Dr. Felistus Makhamara ${ }^{1}$ \\ ${ }^{1}$ Kenyatta University, P. O. Box 43844 - 00100, Nairobi, Kenya. \\ *Author for Correspondence email: moi.edna@ku.ac.ke.
}

Article DOI: https://doi.org/10.37284/eajle.2.1.129

\begin{abstract}
Article history:
ABSTRACT

Received: 16 Mar 2020

Despite the evolution of legal systems in Africa, its development cannot be

Accepted: 28 Mar 2020 realized without the adoption of global practices relevant to the 21 st-century

Published: 04 Apr 2020 complexities. Using data from Kenya, the objective of this paper was to

Keywords: determine people's awareness of legal issues, innovation tools for harnessing research data, and innovations for sustainability. This paper gives a brief

Legal Systems, Innovation,

Participation,

Development,

Sustainability,

Africa. history of government systems in various African countries which existed before colonization and further recommends mechanisms for promoting citizens' legal rights. The paper highlights the administration of legal rights in Kenya citing new innovative tools for general development. It recommends ways that could be embraced for promoting development; the technology system, the rule of law, constitutionalism, democracy and stakeholders' support. The paper concludes that the majority of Kenyan citizens need legal awareness. The possible outcome of the process remains uncertain and open to further stakeholders' inputs. The paper finally recommends the increasing involvement of every stakeholder which is expected to increase the rate of Africa's development for global sustainability.
\end{abstract}

\section{APA CITATION}

Moi, E., Minja, D., \& Makhamara, F. (2020). The Administration of Legal Issues in African Development for Global Sustainability. East African Journal of Law and Ethics, 2(1), 1-9. https://doi.org/10.37284/eajle.2.1.129

\section{CHICAGO CITATION}

Moi, Edna, David Minja, and Felistus Makhamara. 2020. "The Administration of Legal Issues in African Development for Global Sustainability”. East African Journal of Law and Ethics 2 (1), 1-9. https://doi.org/10.37284/eajle.2.1.129.

\section{HARVARD CITATION}

Moi, E., Minja, D. and Makhamara, F. (2020) "The Administration of Legal Issues in African Development for Global Sustainability", East African Journal of Law and Ethics, 2(1), pp. 1-9. doi: 10.37284/eajle.2.1.129. 


\section{IEEE CITATION}

E. Moi, D. Minja, and F. Makhamara, "The Administration of Legal Issues in African Development for Global Sustainability", EAJLE, vol. 2, no. 1, pp. 1-9, Apr. 2020.

\section{MLA CITATION}

Moi, Edna, David Minja, and Felistus Makhamara. "The Administration of Legal Issues in African Development for Global Sustainability”. East African Journal of Law and Ethics, Vol. 2, no. 1, Apr. 2020, pp. 1-9, doi:10.37284/eajle.2.1.129.

\section{INTRODUCTION}

Sustainable development is the process of meeting society's current needs without compromising future generations' ability to do the same. It means promoting economic development that does not deplete natural resources. As part of this effort, public administrators oversee the stewardship of land through the administration of legal rights. Say a little about the role of public administrators

Universities as creators of knowledge are also meant to support this effort. The notion that universities can contribute to regional innovation has been built upon two key ideas; first, universities increase knowledge production through the provision of new scholars and scientific results that can be turned into rights, products, and services (Power \& Malmberg, 2008). Second, the existence of universities in regions can lead to knowledge transfer and exchange. In various ways, it is assumed that universities will contribute to building innovative regional economies. Governments generally can only manage the system indirectly by facilitating the generation of the necessary varieties of..., influencing strategic directions, filling gaps in the system, and encouraging citizen involvement. Societal or cultural innovations, such as new forms of citizen participation in decision-making, may well improve the viability of an innovative system. However, these innovations and public service reforms should not pursue societal purpose only but also economic purposes (Fombad, 2013).

\section{HISTORY AND GOVERNMENT SYSTEMS IN AFRICA}

Angola changed from a one-party Marxist-Leninist system ruled by the Popular Movement for the Liberation of Angola (MPLA), which was in place since independence in 1975, to a multiparty democracy based on a new constitution adopted in 1992. Legislative power is vested in the President, the government, and parliament. Angola provides a good example of public service reform in difficult circumstances. Political rights were widened as part of the 1991-92 reforms that instituted a multiparty system, and guaranteed freedom of association, assembly, speech, and of the press (Browning, 2011).

In Mozambique, politics takes place in a framework of a semi-presidential representative democratic republic, whereby the President of Mozambique is head of state and head of government of a multiparty system. Legislative power is vested in both the government and the Assembly of the Republic. Mozambique has increased its poverty reduction efforts over the years. Its GDP grew from $\$ 2,463$ million in 1990 to $\$ 3,607$ million in 2001, with an annual growth rate reaching 13.9 percent in 2001. The fast-growing sectors are the services industry and agriculture (Kauzya \& Balogun, 2005). The GDP figure in 2018 was $\$ 14,396$ million, Mozambique was number 128 in the ranking of GDP of the 196 countries that were published. The GDP in Mozambique rose \$1,810 million with respect to 2017 (African Economic Outlook, 2019). Despite the global economic slowdown in 2012, growth in Sub-Saharan Africa remained vigorous supported by tough domestic demand and still high commodity prices. In 2012, the region's growth was estimated at 4.7 percent (World Bank, 2013).

In Cameroon, the African Charter for the Public Service serves as an inspiration for the adoption of innovative practices. To redeem its image, the government has taken steps to introduce a National Anti-Corruption Plan, which set up an Ad-hoc anticorruption Committee under the Office of the President. The Committee aggressively pursued the investigation of cases of corruption and imposed sanctions and penalties for proven cases of corruption (Kauzya \& Balogun, 2005). 
Tanzania has taken concrete measures to promote innovation by strengthening public service ethics and accountability. In fact, against the backdrop of the challenges associated with the transition from one-party rule to a competitive multiparty system, the issues of ethics and professionalism had engaged the attention of the government prior to the adoption of the African Public Service Charter. The adoption of the Charter in 2001 provided greater incentive towards the construction of an ethical infrastructure that meets the contemporary standards of good governance (Tillier, 2013). Tanzania's response to on-going challenges began with the establishment of a legal framework with which to combat corruption and promote public service professionalism. Specifically, the government enacted the Prevention of Corruption Act, the Public Service Act of 2002, and the Joint Negotiated Machinery Act that serves as a forum for ironing out labour-management differences. The inauguration of a Performance Management System further reinforced actions taken in recent years to promote ethics and professionalism in the Tanzanian public service. Other measures instituted in support of professionalism in the Tanzanian public service are the implementation of a major public sector reform program; the establishment of appointments committees to screen the qualifications of candidates for vacancies and promote the cause of merit in the selection process. Introduction of mechanisms for performance monitoring; implementation of performancerelated remuneration as well as contributory health and pension schemes, and the involvement of external stakeholders in evaluating the impact and effectiveness of public services are part of the reforms.

The Namibian public service's commitment to quality service began in earnest on the attainment of independence. In 1990, the government enacted the Public Service Commission Act, which empowered the Commission to advise the President on issues of public service recruitment, remuneration, discipline, performance and conduct, among others. This measure was further consolidated with the enactment of the Public Service Act of 1995. The Act bars public servants from engaging in other remunerative pursuits outside their public service employment without due authorization, which is the authorization of the Prime Minister (Devine, 2005).

South Africa has recorded one of the most impressive achievements in public service innovation in Africa. Guided by the slogan "Batho Pele" (meaning People First), the public service has implemented a variety of initiatives aimed at responding to the needs of citizens and non-citizens alike. The Directory of Public Services published by the Department of Public Service and Administration is a testimony to the government's concern for the welfare of South Africans and as well as of foreigners who come in daily contact with the public service (Mashood, 2010).

Kenya had its first constitution in 1963 as a singleparty state. Since gaining independence in 1964, the Kenyan constitution had undergone successive reforms between 1963 and 1991. The most significant amendment was Act No. 12 of 1991, repealing of Section $2 \mathrm{~A}$ of the constitution ending the de jure one-party rule in Kenya and reintroducing multiparty democracy and other electoral reforms. At that period, there was a push for a new Constitution by civil societies, political parties, and reforms aimed towards decentralizing power around the presidency (GoK, 2015). Eventually, a new constitution was enacted in 2010. The August 2010 constitution, which came into force in 2013, made Kenya a two-wheeled devolved state. This is a devolved system of governance that seeks to enhance efficiency, effectiveness, accountability, and transparency in the public sector. The new constitution was pivoted around the people and the impacts of the same on the common citizen epitomized by "Wanjiku" (a term used to refer to the common citizen). This type of government presented a Parliamentary dictatorship with a checked presidency and an ever-flourishing judiciary with the government being accountable to the electorate through various arms of government (Mati, 2012).

Overtime, legislative frameworks, systems, structures, and measures have also been put in place in support of the espousal of the values and principles of the public service in line with the country's vision 2030. Establishment of Article 10 National values and Principles of Governance, Article 73 Responsibility of Leadership, Chapter 13 
The Public Service and Article 232 Values and Principles Public Service in the Constitution emphasize on ten thematic areas of high standards of professional ethics, devolution and powersharing, good governance, diversity management, economic resource use and sustainable development, equitable allocation of opportunities, accountability for improvements to service delivery, performance management and public participation in policymaking. Public institutions have put in place various policies and statutes to improve good governance in Kenya. Mwongozo, a "code of governance for State corporations," addresses matters ranging from the effectiveness of boards, transparency and disclosure, accountability, risk management, internal controls, ethical leadership, and good corporate citizenship. Onestop shops called Huduma service centres provide customer services to citizens from a single location to facilitate ease of payment for government services (Abdala et al., 2015)

\section{Administration of Legal Rights in African Development Today}

Most African governments have established highpowered anti-corruption bodies and have strengthened the enforcement and monitoring mechanisms. Accountability is increasingly becoming a fact of public life. Among the measures specifically adopted to revitalize governance institutions in most African countries are the abolition of one-party rule and the legalization of multiparty competition; the organization and conduct of presidential and legislative elections; the enhancement of policy analysis, budget review, and general oversight capacities of legislatures; the consolidation of the independence of the judiciary, and the empowerment of civic bodies to participate in the political process and to perform various policy promotion and watchdog roles.

Public service reforms are part of the efforts to satisfy the growing demand for African governments to shift attention to the reform of the public service competence, performance, and integrity of the public servants. The career service is gradually being reconfigured into a de-politicized and professional institution. This is due to the reform strategy to improve service delivery through decentralization, institutional restructuring by strengthening the policy formulation and monitoring processes to enhance professionalism in the public sector by improving financial management and accountability through the promotion of good governance and combating corruption and change management (Barros, 2016)

\section{New Innovative Tools in Harnessing Research and Innovations for Development}

Post-conflict and crisis contexts must be carefully managed, starting as early as possible to avoid contemporary conflict in Africa and ensure stability. The implementation of political agreements should be closely monitored, including clear benchmarks, because failures to do this is a major reason for violent conflict re-igniting. It must be borne in mind that extremist ideologies, including ethnic exclusion, are fostered during violent conflict and remain a threat to peace even after agreements have been signed. Transitional justice processes usually do not investigate a whole range of unstated or unspeakable truths, such as economic crimes; external collaborators; and shady financiers who are merchants of terror. The western and eastern foreign capital interests that have fueled conflicts in Africa are never subject to international justice proceedings. Constructing good governance in Africa's development will be determined by some factors that could be more realizable within the context of full adoption of technology, constitutionalism, the rule of law and democracy as well as respect for human rights (International Development Law Organization, 2014) which are the innovative tools to harness research.

\section{Technology Systems}

The technology system has brought about innovative learning environments and has produced a sampling of rich array of new visions for education around the world. Interactivity and collaboration also demonstrate the increased interaction with technology, while integration has long been a key area of concern in education. The intersection of technology with our rapidly transforming educational landscape is framing the nature of technology in education in profound, new ways while serving as catalysts for transformation and innovation for global awareness, creativity, and collaborative problem-solving. Technology is an 
integral part of accessing the higher-order competencies, often referred to as 21 st Century skills, which are also necessary for countries to be productive in today's society. It can perform several key functions in the change process, including opening up new opportunities that improve teaching and learning, particularly provision of affordable learning that is customized to individual learner needs, which is highly supported by the learning institutions. This has continued to decrease the digital divide and to enhance the capacity to effectively operate and thrive in the new knowledge economy (Nardi, 2019)

\section{Constitutionalism and the Rule of Law}

Constitutionalism is very important as all power rests on the understanding that it will be exercised according to commonly accepted principles. Kameri and Akech (2011) asserted that natural law and any moralistic theory of constitutionalism must be a commitment to the law and rule of law. The evolution of democracy and good governance in Africa will require a re-adjustment of economic policies and priorities in Africa away from the present spiritual dependability to the fundamentalist ideology of the development.

Rule of law as a system of self-governance in which the independent judiciary is respected, all persons, including the government are accountable under the law and based on fair, publicized, broadly understood stable laws. The rule of law for the promotion of economic growth ensures that agreements between the private sector and the state are equitably enforced minimizing instances of coercion and predatory behaviour. It also enhances institutional capacity, equity, predictability, transparency, that is, access to information on government processes and legality required for sustainable economic growth. There has to be a fair, robust, and accessible legal process in which rights and responsibilities - based on the law, are evenly enforced. Equally critical is the contribution towards a just social order through strengthening the rule of law. Transitional justice mechanisms have an important role to play in establishing or strengthening the rule of law and in transforming institutions and the social fabric. Because accountability and non-recurrence are purposes of effective transitional justice, mechanisms need to go beyond the legal-judicial aspects to ensure a comprehensive approach that satisfies the people. Transitional justice mechanisms need to meet the basic minimum needs of accountability, including measures of non-recurrence, recognition of massacres committed, and trustworthy compensation (Shivute, 2008).

\section{Democracy and Respect for Human Rights}

The ideology of democracy and equality had taken over centre stage in the discussions of academicians. Democratic states should have a mechanism through which leaders consult and account to the citizenry. Participation by all members of society is a key cornerstone of good governance. Participation could be either direct or through legitimate intermediate institutions or representatives-including public institutions and other elected public officers. It involves the participation of both the public and private sectors. Participation needs to be informed and organized. This means freedom of association and expression on the one hand and organized civil society, on the other hand (Kameri \& Akech, 2011).

Human capacity is critical to successful reforms because of the need for commitment to reforms by all stakeholders and should remain consistent over time though priorities may vary from one stakeholder to another. Leadership in political and managerial spheres is essential to the attainment of reform objectives. Effective management of the change process hinges on effective communication and expectations. The involvement of donors adds to the challenge of reform focus, and of change management and coordination. Differences in capacities and willingness to participate in the reforms across ministries most frequently translate into uncoordinated performance. It is, therefore, advisable to embark on a strategy that identifies and encourages likely 'winners' while not losing sight of those in need of special attention. Managers of public sector reform projects face the risk of concentrating too much on processes and ignoring the more important issue of service delivery outcomes and impact (Browning, 2011). 


\section{METHODOLOGY}

The study was done in two County Governments in North Rift Kenya which were Nandi and Elgeyo Marakwet. This study utilized a descriptive research survey design, a target population were 1,122,963 (KNBS, 2009). Available data showed that the two counties had a low level of legal awareness. Multistage sampling was used in this study to obtain a sample of 400 respondents. In determining the sample size, this study adopted the formula and procedure for categorical data using Fisher's formula. The respondents were citizens, employees of various projects and county officials of various projects in the two counties. Primary data was collected with the help of questionnaires and an interview guide (for the key informants) as the instruments to get the information. The study employed descriptive analysis to get the respondents' awareness on knowledge of the law and their sources that guide legal framework in their counties for the development of projects. The percentages obtain were presented in a graph.

\section{RESULTS AND DISCUSSIONS}

To improve the environment, respondents indicated that every citizen should participate in their country's law formulation; thus, the government should take steps to ensure citizens are given every possibility of access to and understand the constitutional provisions. Figure 1 shows the level of public awareness of the legal frameworks that exist in Kenya. Study results show that most Kenyan citizens (89\%) were not aware of any other legal framework apart from the constitution. Only $56 \%$ of the respondents were aware of constitutional provisions. This implies that there is a need for citizens to be empowered on the existing legal framework in Kenya. This further implies skewed and stagnated development in Africa if citizens have limited knowledge about existing legal frameworks since they are not sure of their responsibilities and obligations.

Capacity bridging and building and citizen empowerment are critical for effective legal systems. Knowledge and skills in the following areas should be enhanced: development, peacebuilding, nation, state-building, consistency, and coordination. Equipping actors across the range of key governmental and non-governmental partners, and not just among traditional legal partners and institutions is also important. This also provides an opportunity for ensuring that systems and structures are transformed for inclusiveness and equity, as well as ensuring citizen representation. The transitional legal framework should form part of an integrated peacebuilding framework that includes the engagement of all relevant actors locally and internationally for development.

\section{Figure 1: Legal framework in Elgeiyo Marakwet and Nandi County Kenya}

Apart from the Kenyan constitution do you know of any other legal frame work guiding County government projects?

Are you aware of the County Government Act ?

Are you aware of the constitutional provision to be involved in the County Developments?

Do you know of the current Kenyan constitution?
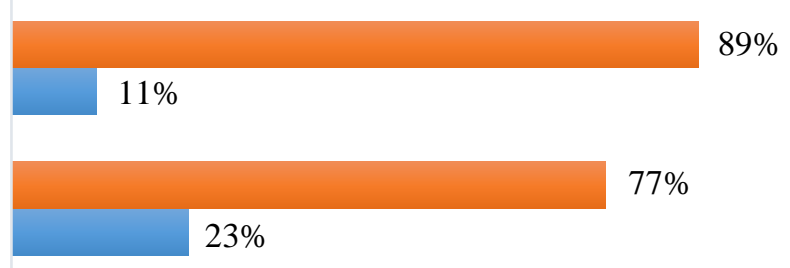

$56 \%$

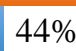

$22 \%$

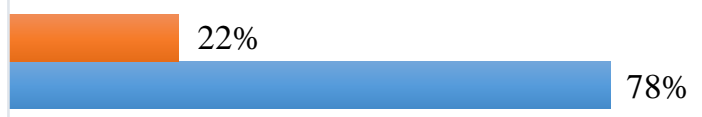

No $\square$ Yes 
For global sustainability legal awareness helps investors to measure, account for and integrate the impact of their investment activity. It is important for environmental legislations, social and health care to improve people's livelihood.

\section{CONCLUSION AND RECOMMENDATION}

Although a lot of hopes and expectations are invested in the current process of capacity building to promote good governance, the possible outcome of the process remains uncertain and open to the estimation of stakeholders' inputs. Most of the Kenyan citizens were not aware of existing legal frameworks except the Constitution. This calls for legal empowerment of citizens. In addition, citizens should know the speed and cost of accessing public services. The simplicity of service procedures and the bureaucratic processes such as the number of decision layers and signatures required to obtain the service need to be well known.

Without the requisite resources, it is difficult to overcome the challenges of managing the crisis, facilitate early recovery, stabilization, peacebuilding, and development. Governmental systems ought to ensure their support builds local capacities and utilizes local resources. They also need to support transitional justice that is comprehensive, transformative, and meets multiple needs and objectives. Investing resources in the conceptual and practical development of transitional justice and nation and state-building as frameworks for prevention is critical. Development partners need to determine, prioritize and safeguard quotas within transitional justice funding and bear in mind that transitional justice, the transformation of relationships, systems and structures, and building social cohesion will take time and heavy financial investment is required for the development and utilization of innovative ways of measuring progress.

The sovereignty of African countries needs to be reasserted as a responsibility, not as a cover for tyranny or a leftover of the past world order. The transformation would be most effective when it starts with the individual community and then the state. Social cohesion and healing cannot be institutionalized or legislated. To achieve, for instance, goals envisioned by Vision 2030, new modalities for development is required, including bringing innovation to the foreground of development projects. It is important to ensure that whatever method is adopted, it has local support and is neither an external imposition nor a top-down national government initiative. The latter, in particular, may yield resistance or apathy resulting in disrupted peace process rather than transformed relationships.

The role of government is to create an enabling environment to facilitate these processes that must be driven by those affected and to allow its members to get involved in their personal capacities as part of their personal journey towards healing. They have to reject amnesties for crimes of genocide, war crimes against humanity, and gross violations of human rights. The process should support favourable national jurisdiction that comprises effective judicial mechanisms, laws, and policies, which incorporate the national ownership of the rule of law principles based on international norms. They should allow for measures of the nation and state-building to be incorporated into transformation and development efforts, so that states become more viable, thus reducing or eliminating risks associated with violent conflict. Countries should create opportunities for more peer learning among the leaders of the continent, develop means of holding each other accountable and supporting each other, and establish a leadership mentoring system to identify and equip the next generation of leaders for smooth political transitions. They should also Build and strengthen sub-regional, regional, and continental capacities, and universities that can provide external assistance that is context-specific.

African governments must shoulder the primary responsibility of providing a business-friendly environment and enacting reforms that are conducive for vibrant private sector growth. Thus, it is imperative that these governments step up domestic resource mobilization efforts and make the right investments in education, skills training, infrastructure, which are fundamentals for any competitiveness agenda.

Non-governmental organizations need also to play an active and constructively critical role to ensure transitional justice process is comprehensive, 
transformative, and meets multiple needs and objectives. To provide human resources and expertise to contribute to these objectives, knowledge and expertise in conflict prevention and transformation, peacebuilding, nation, and statebuilding, and trauma healing, in addition to traditional legal and the rule of law expertise should be enhanced. These organizations should play a dynamic accountability role to ensure that the said mechanisms have local support and meet citizens' needs. They should be actively engaged in coordinated, regular, systematic, and structured conflict and context analysis as part of democracy and the rule of law assessments, using tools that are context-specific. They should be able to identify and point out potential or actual cases of political exclusion and repression, state fragility and viability, conflict early warning signs, and disaster risk preparedness and reduction. As part of the nation and state-building efforts, work towards the formation of parallel transformation of civil society applying similar principles to contribute to more viable states should be encouraged.

\section{REFERENCES}

Abdalla, A. G., Kiragu, J. K., Waswa, F. A., Ono, F. T., Kariuki, J. W., \& Ikua, D. M. (2015). Effect of Huduma centers (one-stop shops) in service delivery-A case study of Mombasa Huduma Centre. International Journal of Academic Research in Business and Social Sciences, 5(6), 102-117.

Barros, C. P. (2016). Country survey: Angola. Defense and Peace Economics, 27(3), 423-432.

Browning, R. (2011). The Right to Development in Africa: An Emerging Jurisprudence? Examining the Endorois recommendation by the African Commission for Human and People's Rights. African Commission for Human and People's Rights-University of Cape Town August.

Devine, S. (2005). The viable systems model applied to a national system of innovation to inform policy development. Systemic Practice and Action Research, 18(5), 491-517.

Kauzya, J. M., \& Balogun, J. (2005). Governance and public administration reforms and innovations in African countries: A focus on achievements, setbacks and future directions. Regional Forum on Reinventing Government in Africa: Repositioning the Public Sector for the Challenges of NEPAD. Johannesburg, South Africa: Sandton Convention Centre.

Fombad, C. M. (2013). The context of justice in Africa: Emerging trends and prospects. In Edroma, E., Rethinking the Role of Law and Justice in Africa's Development - An Edited Volume of Discussion Paper. Addis Ababa, Ethiopia: United Nations Development Programme.

GoK. (2015). The working group on socioeconomic audit of the Constitution of Kenya 2010.

Kameri, P. M., \& Akech, M. (2011). Kenya: Justice Sector and the Rule of Law. Nairobi: The Open Society Initiative for Eastern Africa.

Mashood, B. (2010). Law and Development in Africa: Towards the New Approach. NIALS Journal of Law and Development.

Mati, J. M. (2012). The power and limits of social movements in promoting political and constitutional change: the case of the Ufungamano Initiative in Kenya (19992005) (Doctoral dissertation). University of the Witwatersrand.

Nardi, M. L. (2019). Risk and Benefit of Effective Techniques and Technologies in Education: A Historical Overview. In Forecasting and Managing Risk in the Health and Safety Sectors (pp. 175-200). IGI Global.

Nmehielle, V. O. (2004). Development of the African human rights system in the last decade. Human Rights Brief, 11(3), 6-11.

Power, D., \& Malmberg, A. (2008). The contribution of universities to innovation and economic development: in what sense a regional problem? Cambridge journal of regions, economy and society, 1(2), 233-245.

Shivute, P. (2008). The rule of law in sub-Saharan Africa-An overview. Human rights and the rule of law in Namibia, 213, 215. 
The International Development Law Organization (2014). Integrating the Rule of Law in Sustainable Development. Doing Justice to Development: Integrating the Rule of Law into the Post-2015 Development Agenda, 23-39.

Tillier, J. (2013). The ICC Prosecutor and Positive Complementarity: Strengthening the Rule of Law? International Criminal Law Review, 13(3), 507-591.

World Bank. (2013). Africa's pulse. An analysis of issues shaping Africa's economic future (Vol 7). Washington, DC: World Bank. 